\title{
Self-perceived Incentives and Disincentives of Untreated Waste Water Irrigation in Vegetables in Peri-Urban Areas of Pakistan
}

\author{
Muhammad Luqman, Rahman Shoukat, Xu Shiwei, Yu Wen, and Muhammad Yaseen
}

\begin{abstract}
With the increase in human population in developing countries including Pakistan and shortage of canal irrigation water, people used to think about other alternate irrigation sources particularly in peri-urban areas, where most of the farming activities are depend upon waste water. Pakistan is also included in the list of those where untreated waste water application on vegetables is very common. Based on the theoretical debate on its advantages and disadvantages, the present study was designed to know about the incentives and disincentives of untreated wastewater application in vegetables. The study was conducted in the Punjab province. Quantitative data were collected through reliable and validated research instrument (interview schedule) and analyzed through SPSS. It was concluded from the results that majority of the respondents $(55.8 \%)$ had education only upto eight $(08)$ years of schooling. About 69.2\% of the respondents were small land holders and considered as tenant. Majority of the majority of the vegetable growers in the research area used to grow vegetables from more than 10 years. Shortage of can irrigation water, power/energy crises in Pakistan, and high cost of fresh water through tube well were the main reasons behind application of untreated waste water for vegetable farming. Out of different incentives of waste water application in vegetables, high yield was on the top with maximum mean $(\bar{x}=4.13)$. Health problems were the main disincentives of wastewater application in vegetable due to its high mean $(\overline{\mathbf{x}}=4.42)$ out of others. Overall mean of all the disincentives $(\bar{x}=4.61)$ is high compared to overall mean of all the incentives $(\bar{x}=4.13)$. It was recommended that water treatment facilities should be provided by the government on subsidized rates as small scale vegetable growers didn't have enough financial and physical capitals.
\end{abstract}

Index Terms-Disincentives, incentives, Pakistan, vegetable farming, wastewater.

\section{INTRODUCTION}

Human beings are always interested in good quality food due to its positive impacts on health [1]. This has been proved that daily intake of vegetables in diet have strong association with reduced health risks. It is highly recommended by nutritionists that vegetables are too much essential for having good health status due to the high concentration of vitamins, carbohydrates and minerals [2]-[5]. Due to the importance of vegetables generally in human diet and particularly in

Manuscript received July 5, 2016; revised October 12, 2016. This work was conducted at University College of Agriculture, University of Sargodha, Pakistan.

The authors are with the Department of Agri. Extension \& Rural Development, University College of Agriculture, University of Sargodha, Pakistan and Agricultural Information Institute (AII) of CCAS, Beijing, China (e-mail: muhammadluqman_uos@yahoo.com). reducing health associated risks, vegetables are widely grown in all over the world including developing countries. Particularly in South Asia and Pacific region, vegetables are mostly grown by small scale farmers, who have limited financial and physical resources [6]. Nature bestowed Pakistan with good climate which is very much suitable for variety of vegetables than fruits and field crops [7].

Due to rapid growth in population and urbanization in Pakistan, there is an increasing demand of vegetables and other diversified nature of foods [8]. There is an increasing trend of vegetables farming during the last decade [9]. According to the estimate of [10] there is an increase in per capita monthly consumption of vegetables at rate of about $7.27 \%$. This increasing demand of vegetable production particularly in big metropolitan cities of Pakistan increases the demand of water for irrigation in vegetables. In farming, the role of irrigation is inevitable. Its role is very much prominent in the economic development of any country on one hand and in reducing poverty and hunger on the other hand [11], [12]. But with the increase in population round the globe especially in developing countries, the gap between supply and demand of water for irrigation is increasing day by day [13]. This situation is very much similar to Pakistan inspite of having world's largest canal irrigation system [14]. High population growth rate, which is 1.89 [15], put high pressure on agricultural production as well on irrigation means [16]. The increasing demand of irrigation water in Pakistan is mainly responsible for scarcity of water for irrigation purposes which is also associated with global climate change [17]. And Pakistan is included in the list of top ten countries of the world having adverse impacts of climate change [18].

In the above mentioned situation of increased demands of vegetables and shortage of canal irrigation water during the last ten years, vegetable growers look for other alternate means of irrigation [19]. Out of these means use of untreated waste water for irrigation in vegetables is very common practice especially in peri-urban areas of big cities like Karachi, Lahore, Peshawar, Faisalabad and other cities of Pakistan [20].

Regarding advantages and disadvantages of waste water irrigation in vegetables, there is a bid debate especially waste water usage without treatment. For example [21] reported that use of waste water in irrigation of vegetables provide enriched nutrients. Vegetable growers rely more on application of waste water due to its timely availability and also in term of its volume [19]. The profit rate while using untreated waste water for irrigation in vegetables is much higher as compared 
to freshwater. And same is also in the case of canal water, as the volume of canal water is decreasing day by day and farmers prefer to apply canal water on field crops. The other reason is the limited availability of canal irrigation water in peri-urban areas [22]. The other side of the picture is the adverse impacts of using untreated waste water for irrigation in vegetables. Its permanent and long-term use for irrigation purposes resulted in increased concentration of heavy metals in soil [23]. In vegetables, its use cause transfer of heavy metals to human food chain, ultimately causing number of health related issues [24]. Numerous research studies provide empirical evidences regarding health issues associated with untreated waste water application in vegetables [25]-[28]. Keeping in view the advantages and disadvantages of untreated wastewater application in vegetable farming round the globe, the study in hand was designed. The main objective of the study was to find out the incentives and disincentives of using untreated wastewater as irrigation in vegetables in per-urban areas of Pakistan.

\section{MATERIALS AND METHODS}

\section{A. Research Area}

Pakistan is administratively divided into four provinces as Punjab, Sindh, Khyber Pakhtunkhwa and Baluchistan. On population basis Punjab is the largest province of Pakistan and majority of the agricultural activities are being carried out in that province. The present study was also conducted in the Punjab province due to its diverse nature of soil and climate which is very much suitable for production of variety of vegetables. The other rational behind its selection as study area was its major share in vegetable production (except potato) in the country [29] as clear from the data given in Table I:

TABLE I: PRovince Wise AREA AND PRoduction of Vegetables

\begin{tabular}{lcc}
\hline \hline Province & Area (Hectares) & Production (Tonnes) \\
\hline Punjab & 136059 & 2059702 \\
Sindh & 36585 & 246676 \\
Khyber Pakhtunkhwa & 40370 & 412490 \\
Baluchistan & 39924 & 495032 \\
\hline \hline
\end{tabular}

Government of Pakistan, 2009

\section{B. Targeted Districts}

Total number of districts in the Punjab are 36 and geographically divided into southern, central and northern parts. Compared to other provinces of Pakistan massive urbanization is found in Punjab whose economy was traditionally agrarian based and now transform into industrial and service based. And this is very much common in central areas of the Punjab where majority of the populated metropolitan cities present [30]. Three (03) districts from the central part of the province were purposively selected as the targeted districts for this study as Lahore, Faisalabad and Sargodha.

\section{Sampling Procedure}

As the study was exploratory in nature, so two type of sampling techniques were adopted for the selection of study objects. For the selection of targeted districts out from the 36 districts of the Punjab, purposive sampling technique was used. But for the selection of objects (respondents) from the selected districts simple random sampling was used.

\section{Sampling Frame and Selection of Study Respondents}

List of vegetable growers each from the selected three districts of the Punjab was prepared with the help of Agriculture Department, Government of The Punjab (Extension Wing). The vegetable growers were then separated on the basis of wastewater use for vegetable farming. From each list 40 vegetable growers were selected through simple random sampling and interviewed. The total sample size of the study was 120 vegetable growers.

\section{E. Data Collection Procedure and Analysis}

The nature of the study was quantitative in nature and cross-sectional survey research design was used. The data were collected with the help of structured interview schedule designed keeping in mind the main objective of the study. The collected data were analyzed by using SPSS and interpreted with the help of descriptive statistics.

\section{RESULTS AND DISCUSSIONS}

\section{A. Demographic Profile}

In social science research studies the significance of demographic profile of respondents is well established and already explained by different researchers [31], [32]. In this research study data regarding selected demographic characteristics (education, income sources, tenancy status and vegetable farming experience) were collected and presented in Table II and III:

TABLE II: DEMOGRAPHIC PROFILE

\begin{tabular}{lcc} 
& & $\mathbf{n = 1 2 0}$ \\
\hline \hline Education & Frequency & Percentage \\
\hline Primary & 34 & 28.3 \\
Middle & 67 & 55.8 \\
Matriculation & 19 & 15.8 \\
Sources of Income & & \\
Farming & 94 & 78.3 \\
Both Farming and & 26 & 21.7 \\
non-Farming & & \\
Farm Size & 83 & 69.2 \\
Upto 10 acres & 31 & 25.8 \\
11 to 20 Acres & 06 & 5.0 \\
21 Acres and above & & \\
Tenancy status & 13 & 10.8 \\
Owner & 107 & 89.2 \\
Tenant & & \\
\hline \hline
\end{tabular}

The data regarding educational status of respondents as presented in Table II shows low literacy level of vegetable growers. More than half of the respondents $(55.8 \%)$ had education only upto eight (08) years of schooling (middle). Only small percentage of vegetable growers (15.8\%) had education upto matriculation. Low level of education among vegetable growers is mainly responsible for little knowledge and awareness about health issues associated with use of untreated wastewater for irrigation in vegetables. Regarding income sources of respondents, high majority $(78.3 \%)$ of the respondents said that farming is their major source of income. This is very common in rural areas of Pakistan that rural 
households used to earn income from farm related activities. High dependency rate on farming as livelihood strategies is one of the major reasons of high poverty rate in rural areas of Pakistan [33].

The data regarding size of land holding shows that a considerable majority $(69.2 \%)$ of the respondents had land upto 10 acres. This shows that small land holders were in majority in the research area. In connection with the findings of the present research [34] concluded that small land holders have minimum financial and physical resources. Due to which they used to cultivate vegetables due to low cost of production and high economic returns. On similar lines [35] also concluded that in central Punjab (district Sargodha) majority of the vegetable growers who used to apply wastewater had very small land holdings. The data regarding tenancy status of respondents as presented in Table 01 shows that an overwhelming majority (89.2\%) of the respondents didn't had their own land for vegetable farming and they were considered as tenant. Only $10.8 \%$ of respondents had their own land and they used to do vegetable farming. This shows that vegetable growers had low level of financial and physical capitals. Due to which they mostly used to grow vegetables due to minimum production cost in the form of inputs and high value of return [34]. In connection with the results of present study [36] concluded that in Pakistan most of the vegetable growers didn't have their own land for vegetable farming, they used to rent land from large land holders.

\section{B. Vegetable Growing Experience}

The vegetable growing experience of respondents was measured and data in this regard is tabulated in Table III:

TABLE III: Minimum, MaXimum AND MeAn Years of Vegetable

\begin{tabular}{ccc} 
& FARMING & \\
\hline \hline Minimum & Maximum & Mean \\
3 Years & 23 Years & 12.8 Years \\
\hline \hline
\end{tabular}

The data given in Table III shows that minimum year of vegetable farming were 3 and maximum years were 23. The average or mean years of vegetable farming is reported by respondents were 12.8. This showed that majority of the majority of the vegetable growers in the research area used to grow vegetables from more than 10 years.

\section{Major Reasons of Using Wastewater for Irrigation in Vegetables}

Major reasons as pointed out by respondents behind use of wastewater for irrigation in Vegetables are given in Table IV:

TABLE IV: FREQUENCY DISTRIBUTION OF MAJOR REASONS OF USING WASTEWATER FOR IRRIGATION IN VEGETABLES

\begin{tabular}{lcc}
\hline \hline Reason & Frequency & Percentage \\
\hline Shortage of canal water irrigation & 120 & 100.0 \\
High cost of canal irrigation water & 73 & 60.8 \\
High cost of tube well (fresh water) & 114 & 95.0 \\
Energy crises/electricity problems in case & 120 & 100.0 \\
of use of tube well water for irrigation & 87 & 72.5 \\
Easily available in per-urban areas & 96 & 80.0 \\
Perception is that vegetable production is & 92 & 76.7 \\
higher in case of waste water irrigation & 89 & 74.2 \\
Timely available & 103 & 85.8 \\
Cost saving & & \\
Increased vegetable demand in cities & & \\
\hline \hline
\end{tabular}

Table IV showed that major reasons due to which respondents use wastewater for irrigation in vegetables were shortage of canal water irrigation, high cost of canal irrigation water, high cost of tube well (fresh water), Energy crises/electricity problems in case of use of tube well water for irrigation, easily available in per-urban areas, Perception is that vegetable production is higher in case of waste water irrigation, timely available, cost saving, increased demand of vegetables in cities as reported by $100.0 \%, 60.8 \%, 95.0 \%$, $100.0 \%, 72.5 \%, 80.0 \%, 76.7 \%, 74.2 \%$ and $85.58 \%$ respectively. This showed that shortage of can irrigation water, power/energy crises in Pakistan, and high cost of fresh water through tube well were the main reasons behind application of untreated waste water for vegetable farming.

\section{Perceived Incentives of Waste Water Irrigation in Vegetables}

Incentives of using wastewater for irrigation purposes in vegetables as perceived by respondents are measured with the help of five point likert scale $(1=\mathrm{S}$. Disagree, $2=$ Disagree, $3=$ Undecided, 4= Agree, 5= S. Agree). The mean and SD of these incentives is given in Table $\mathrm{V}$ :

TABLE V: MEAN AND SD REGARDING INCENTIVES OF WASTE WATER IRRIGATION IN VEGETABLES

\begin{tabular}{lcc}
\hline \hline Perceived incentives & Mean & SD \\
\hline High yield & 4.13 & 0.898 \\
Prevention from sanitary and pollution & 3.98 & 0.965 \\
problems & 3.93 & 0.521 \\
Additional irrigation water source & 3.49 & 0.979 \\
Reduction in demand of fertilizers & 3.48 & 1.004 \\
Saving of canal water in case of water & 3.41 & 1.033 \\
shortage & 3.38 & 1.013 \\
Presence of excessive plant nutrients & 3.29 & 1.064 \\
Easy method to dispose waste water & 3.20 & 0.992 \\
Continuous availability & $\mathbf{3 . 5 9}$ & $\mathbf{0 . 9 4 1}$ \\
Saving of canal water for other crops & & \\
Overall Mean &
\end{tabular}

The data given in Table $\mathrm{V}$ shows that out of different incentives of waste water application in vegetables as perceived by respondents, "high yield" was on the top with maximum mean $(\bar{x}=4.13)$. This showed that in all the incentives, the response of respondents was found to be undecided to agree. The overall mean $(\bar{x}=4.13)$ of all the incentives also showed that majority of the respondents somewhat agreed regarding incentives of wastewater application in vegetables.

\section{E. Perceived Disincentives of Waste Water Irrigation in Vegetables}

Disincentives with regard to application of waste water in vegetables were also find out by using five point likert scale $(1=\mathrm{S}$. Disagree, $2=$ Disagree, $3=$ Undecided, 4= Agree, $5=\mathrm{S}$. Agree). Mean and SD of these disincentives was calculated through SPSS and tabulated in Table VI:

The data given in Table VI shows that health problems were the main disincentives of wastewater application in vegetable due to its high mean $(\bar{x}=4.42)$ out of others. The other disincentives as reported by respondents on the basis of their self-perception were Presence of high concentration of toxic elements, cause water pollution, high breeding of mosquitoes, some chemicals are dangerous to plant health, disturb ecosystem, contamination of heavy metals in human 
and animal body, reduction in quality of vegetables, excessive vegetative growth in plants and Contamination of ground fresh water having mean 4.27, 4.27, 4.26, 4.22, 4.13, 4.07, $4.03,3.98$ and 3.87 , respectively. This showed that in all the disincentives, the response of majority of the respondents were agreed towards strongly agree. This indicates that respondents were fully aware of regarding adverse impacts of using untreated wastewater in vegetable farming. Here, this is very much important to mention that overall mean of all the disincentives $(\overline{\mathrm{x}}=4.61)$ is high compared to overall mean of all the incentives $(\bar{x}=4.13)$. This indicates that respondents agreed at higher rate regarding disincentives compared to incentives of untreated wastewater for irrigation in vegetables. But they used to do this continuously due to one or other reasons (as explained in Table III). The others reasons as explored during discussion with respondents were limited awareness level of vegetable growers regarding treatment of wastewater and lack of availability of infrastructure for wastewater treatment as well as its high cost.

TABLE VI: MEAN AND SD REGARDING DISINCENTIVES OF WASTE WATER IRRIGATION IN VEGETABLES

\begin{tabular}{lcc}
\hline \hline Perceived disincentives & Mean & SD \\
\hline Health problems & 4.42 & 0.511 \\
$\begin{array}{l}\text { Presence of high concentration of toxic } \\
\text { elements }\end{array}$ & 4.27 & 0.683 \\
Cause water pollution & 4.27 & 0.590 \\
High breeding of mosquitoes & 4.26 & 0.692 \\
Some chemicals are dangerous to plant & & \\
health & 4.22 & 0.735 \\
Disturb ecosystem & & \\
Contamination of heavy metals in human & 4.13 & 0.709 \\
and animal body & 4.07 & 0.775 \\
Reduction in quality of vegetables & 4.03 & 0.526 \\
Excessive vegetative growth in plants & 3.98 & 1.073 \\
Contamination of ground fresh water & 3.87 & 1.012 \\
Overall Mean & $\mathbf{4 . 6 1}$ & $\mathbf{0 . 8 1 2}$ \\
\hline \hline
\end{tabular}

\section{CONCLUSION}

It was concluded that majority of the respondents (55.8\%) had education only upto eight (08) years of schooling. Majority of the respondents were small land holders and had land upto 10 acres and didn't had their own land for cultivation. The average years of vegetable farming were 12.8 as majority of the majority of the vegetable growers in the research area used to grow vegetables from more than 10 years. Shortage of can irrigation water, power/energy crises in Pakistan, and high cost of fresh water through tube well were the main reasons behind application of untreated waste water for vegetable farming. Out of different incentives of waste water application in vegetables as perceived by respondents, "high yield" was on the top with maximum mean ( $\bar{x}=4.13)$. The overall mean $(\bar{x}=4.13)$ of all the incentives also showed that majority of the respondents somewhat agreed regarding incentives of wastewater application in vegetables. Health problems were the main disincentives of wastewater application in vegetable due to its high mean $(\bar{x}=4.42)$ out of others. Overall mean of all the disincentives $(\bar{x}=4.61)$ is high compared to overall mean of all the incentives $(\overline{\mathrm{x}}=4.13)$.

\section{RECOMMENDATIONS}

Following recommendations are hereby formulated keeping in view the findings of study:

- Awareness campaigns should be started at farm level regarding bad impacts of untreated wastewater application on human health

- Extension and advisory services should be provided to vegetable growers regarding low cost of treating wastewater and its use for irrigation

- Educational status of farmers should be increased

- Government should provide water treatment facilities at farm level on subsidized rates

\section{ACKNOWLEDGMENT}

The authors thanks for financial support of Punjab Higher Education Commission, Pakistan.

\section{REFERENCES}

[1] A. Kader, "Importance of fruits, nuts, and vegetables in human nutrition and health," Perishables Handling Quarterly, vol. 106, pp. 4-6, May 2001.

[2] R. L. Prior and G. Cao. "Antioxidant phytochemicals in fruits and vegetables; diet and health implications," HortScience, vol. 35, pp. 588-592, July 2000

[3] R. Hanif, Z. Iqbal., M. Iqbal, S. Hanif and M. Rasheed. "Role of vegetables in nutritional food: Role in Human Health," Journal of Agriculture \& Biological Sciences, vol. 1, pp. 18-22, July 2006.

[4] J. L. Slavin and B. Lloyd, "Health benefits of fruits and vegetables," Advances in Nutrition, vol. 3, pp. 506-516, May 2012.

[5] D. Pem and R. Jeewon. "Fruit and vegetable intake: Benefits and progress of nutrition education interventions - Narrative review article," Iranian Journal of Public Health, vol. 44, pp. 1309-1321, October 2015.

[6] K.-Y. Shin, "Recent development in vegetable and fruit marketing in marketing of vegetables and fruits in Asia and the Pacific," Asian Productivity Organization (APO), Tokyo, Japan, November 2006.

[7] J. K. Bajkani, K. Ahmed, M. Afzal, N. Sadiq, and M. N. Irshad, "Economic analysis cost of production of major vegetables in Baluchistan, Pakistan," Journal of Agriculture and Veterinary Science, vol. 6, pp. 12-19, November-December 2013.

[8] M. Fayaz, A.U. Jan, and D. Jan. "Quality elasticity of vegetable consumption in Pakistan: A comparison urban and rural households," Serhad Journal of Agriculture, vol. 30, pp. 451-458, August 2015.

[9] Government of Pakista, Agriculture Statistics of Pakistan, Pakistan Bureau of Statistics, Islamabad, Pakistan, July 2015.

[10] Government of Pakistan, Pakistan Social And Living Standard Measurement Survey 2010-11, Federal Bureau of Statistics, Islamabad, Pakistan, October 2011.

[11] L. Michael. "Farm water and rural poverty reduction in developing Asia," Journal of International Commission on Irrigation and Drainage, vol. 56, pp. 127-146, March 2007.

[12] A. M. Chandra and F. Helen, "Irrigation in the context of today's global food crisis," Irrigation and Drainage, vol. 59, pp. 40-52, January, 2010.

[13] E. C. Akujuobi, O. A. Marshal, O. O. Donatus, A. Henri-Ukoha, S. C. Onyemauwa, G. N. Ben-Chendo, and O. U. Munonye, "Effects of waste water use on vegetable crop production in Imo state, Nigeria," Researcher, vol. 2, pp. 47-56, October, 2010.

[14] A. R. Ghumman, R. A. Khan, H. N. Hashmi, M. A. Kamal, and I. T. Khan, "Performance assessment of canal irrigation in Pakistan," African Journal of Agricultural Research, vol. 6, pp. 2692-698, June 2011

[15] Government of Pakistan. Economic Survey of Pakistan. Economic Advisors' Wing, Islamabad, Pakistan, June 2016.

[16] M. Asif, "Climatic change, irrigation water crisis and food security in Pakistan," Master thesis, Dept. of Earth Sciences, Uppsala Univ., Uppsala, 2013.

[17] T. H. Khan, "Water scarcity and its impact on agriculture - Case study of Layyah, Pakistan," Master thesis, Dept. Urban \& Rural Development. Uppsala Univ., Uppsala. 
[18] S. Harmeling and E. D. Ckstein, "Global climate risk index 2013: Who suffers most from extreme weather events? Weather-related loss events in 2011 and 1992 to 2011. German watch: A briefing paper," November 2012.

[19] S. Parveen, A. Samad, W. Nazif, and S. Shah. "Impact of sewage water on vegetable quality with respect to heavy metals in Peshawar Pakistan," Pakistan Journal of Botany, vol. 44, pp. 1923-1931, December 2012.

[20] H. Ullah, I. Khan, and I. Ullah, "Impact of sewage contaminated water on soil, vegetables, and underground water of peri-urban Peshawar, Pakistan," Environmental Monitoring \& Assessment, vol. 84, pp. 6411-6421, October 2012.

[21] A. K. Ghosh, M. A. Bhatt and H. P. Agrawa, "Effect of long-term application of treated sewage water on heavy metal accumulation in vegetables grown in northern India," Environmental Monitoring \& Assessment, vol. 184, pp. 1025-1036, January 2012.

[22] J. H. J. Ensink, T. Mahmood, W. Hoek, L. Raschid-Sally, and F. P. Amera-Singhe, "A nation-wide assessment of waste water use in Pakistan: an obscure activity or a vitally important one," Water Policy, vol. 6, pp. 1-10, June 2004

[23] S. Khan, Q. Cao, Y. M. Zheng, Y. Z. Huang, and Y. G. Zhu, "Health risks of heavy metals in contaminated soils and food crops irrigated with wastewater in Beijing, China," Environmental Pollution, vol. 152 pp. 686-692, April 2008.

[24] S. Gupta, S. Satpati, S. Nayek, and D. Garai. "Effect of wastewater irrigation on vegetables in relation to bioaccumulation of heavy metals and biochemical changes," Environmental Monitoring \& Assessment, vol. 165, pp. 169-177, June 2011.

[25] M. Qadir, D. Wichelns, L. Raschid-Sally, P. G. McCornick, P. Dreschsel, A. Bahri, and P. S. Minhas. "The challenges of waste water irrigation in developing countries," Agricultural Water Management, vol. 97, pp. 561-568, April 2010.

[26] A. Singh, R. K. Sharma, M. Agarwal, and F. M. Marshall, "Health risk assessment of heavy metals in dietary intake of foodstuffs from the wastewater irrigated site of a dry tropical areas of India," Food Chemistry and Toxicology, vol. 48, pp. 611-619, February 2010.

[27] H. Ullah and I. Khan, "Effects of sewage water irrigation of cabbage to soil geochemical properties and products safety in peri-urban Peshawar, Pakistan," Environmental Monitoring \& Assessment, vol. 187, pp. 125, March 2015

[28] O. P. Bansal and G. Singh, "Investigation of heavy metal status in soil and vegetable grown in sewage effluent water irrigated soil of Aligarh: A five years study," Research Journal of Agricultural and Environmental Sciences, vol. 2, pp. 10-15, March-April 2015.

[29] Government of Pakistan, "Fruit, Vegetables and condiments statistics of Pakistan 2008-09," Ministry of Food \& Agriculture (Economic Wing), Islamabad, Pakistan. June 2009.

[30] D. Dowall and P. Ellis, "Urban lands and housing markets in the Punjab, Pakistan," Working Paper 2007-04, Institute of Urban \& Regional Development (IURD), Berkeley, University of California, USA, April 2007.
[31] D. Frear, "Rural female entrepreneurs: A demographic survey in rura Pennsylvania," Journal of Business and Public Affairs, vol. 1, pp. 12-21, June 2007.

[32] F. Nosheen, T. Ali, M. Ahmad, and H. Nawaz, "Exploring the gender involvement in agricultural decision making: a case study of district Chakwal," Pakistan Journal of Agricultural Sciences, vol. 45, pp. 101-106, September 2008.

[33] M. Luqman, S. Xu., Y. Wen, M. Yaseen, and L. Gao, "Impact of micro-credit on livelihoods of rural poor in the Punjab, Pakistan," Open Journal of Social Sciences, vol. 4, pp. 305-313, May 2016

[34] S. Shaheen, M. H. Sial, G. Sarwar, and R. Munir, "Nexus between human capital and technical efficiency of cauliflower growers in soon valley, Punjab: A panel data analysis," International Journal of Humanities and Social Science, vol. 1, pp. 129-135, October, 2011.

[35] E. Ashraf, F. Shah, M. Luqman, Samiullah, M. Younis, I. Aziz, and U Farooq, "Use of untreated wastewater for vegetable farming: A threat to food safety," International Journal of Agriculture \& Applied Sciences, vol. 5, pp. 27-33, June 2013.

[36] S. Noonari, I. N. Memon, S. U. Solangi, M. A. Leghari, S. A. Wagan, A. A. Sethar, G. Y. Kalyar, A. S. Korejo, A. S. Jamro, and G. M. Panhar, "Economic implications of tomato production in naushahro feroze district of Sindh Pakistan," Research on Humanities and Social Sciences, vol. 5, no. 7, pp. 158-170, July 2015.

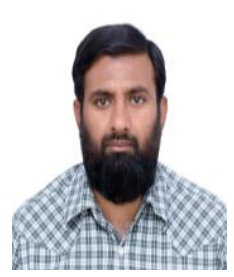

Muhammad Luqman completed his doctoral degree from Institute of Agri. Extension \& Rural Development, University of Agriculture, Faisalabad, Pakistan as research scholar of National Center for Competence in Research (NCCR) North-South, Switzerland. Currently he is doing post doctorate fellowship at Agricultural Information Institute of CAAS, Beijing, China. He is working as assistant professor in the Department of Agricultural Extension Education, University College of Agriculture, University of Sargodha, Pakistan. He has completed his Post Doctorate training from University of California, Davis, USA in 2015. He is involved in teaching and research from the last ten years and in communicating the innovative agricultural technologies to the farming community of Pakistan. He is involved in different research/outreach activities of different national and international organizations like Higher Education Commission, Pakistan; Sustainable Development Policy Institute, Islamabad; U.S.-Pakistan Centers for Advanced Studies in Agriculture \& Food Security, The University of Queensland, Australia etc. More than 35 research papers in research journals; one book, one chapter in edited book and articles in newspapers/magazines are on his credit. He has attended many national and international conferences, symposia and workshops. His research interests are Agricultural Extension Systems, Gender involvement in Agriculture, Women Empowerment, Food Security \& Livelihoods and recent trends in Rural Development. 